\title{
Declines of Aerial Insectivores in North America Follow a Geographic Gradient
}

\section{Présence d'un gradient géographique dans le déclin des insectivores aériens}

$\underline{\text { Silke Nebel }}^{1}, \underline{\text { Alex Mills }}^{2}, \underline{\text { Jon D.McCracken }}^{3}$, and $_{\text {Philip D. Taylor }}{ }^{3}$

\begin{abstract}
North American birds that feed on aerial insects are experiencing widespread population declines. An analysis of the North American Breeding Bird Survey trend estimates for 1966 to 2006 suggests that declines in this guild are significantly stronger than in passerines in general. The pattern of decline also shows a striking geographical gradient, with aerial insectivore declines becoming more prevalent towards the northeast of North America. Declines are also more acute in species that migrate long distances compared to those that migrate short distances. The declines become manifest, almost without exception, in the mid 1980s. The taxonomic breadth of these downward trends suggests that declines in aerial insectivore populations are linked to changes in populations of flying insects, and these changes might be indicative of underlying ecosystem changes.
\end{abstract}

RÉSUMÉ. Les populations d'oiseaux nord-américains qui se nourrissent d'insectes aériens montrent un déclin à grande échelle. Une analyse des données de tendance du Relevé des oiseux nicheurs (BBS) en Amérique du Nord de 1966 à 2006 indique que les déclins dans cette guilde sont plus importants que ceux qui sont observés chez les passereaux en général, et ce, de façon significative. Le profil des déclins montre également un gradient géographique frappant, la diminution des insectivores aériens devenant plus fréquente vers le nord-est de l'Amérique du Nord. La baisse est aussi plus marquée chez les espèces qui migrent sur de longues distances, comparativement à celle observée chez les espèces qui migrent sur de courtes distances. Ces déclins sont devenus évidents, presque sans exceptions, dans le milieu des années 1980. L'ampleur taxinomique de ces tendances à la baisse donne à penser que le déclin des populations d'insectivores aériens est lié aux changements dans les populations d'insectes volants, ces derniers étant possiblement le reflet de modifications au plan de l'écosystème.

Key Words: aerial insectivores, geographical gradient, migration distance, migratory birds, North American Breeding Bird Survey, population decline 


\section{INTRODUCTION}

An increasing number of the migratory bird species in North America that are considered vulnerable to extinction belong to the aerial insectivores, a guild which encompasses birds that feed on flying insects (COSEWIC 2008). Declines in this guild were first noted in the early 1990s (Böhning-Gaese et al. 1993) and are apparent from inspection of the Breeding Bird Survey (BBS) trends (Sauer et al. 2007). More recently, declines have also been manifested through major changes of ranges that were detected in 'second generation' breeding bird atlas projects in Ontario (Cadman et al. 2007), New York state (McGowan and Corwin 2008), and the Canadian Maritime provinces (Bird Studies Canada 2010). Our aim was to assess the geographical patterns of decline in these species, and to explore correlative variables that might suggest underlying causes of those declines.

Although loss of habitat is thought to be a prevalent driver of population declines for many bird species (Andren 1994, Robinson et al. 1995, MacHunter et al. 2006) other factors include increases in predator populations (Ydenberg et al. 2004, Baines 2008), exceptional mortality events connected to weather (Sauer et al. 1996, Stokke et al. 2005, Dionne et al. 2008), excessive persecution, and brood parasitism (Ward and Schlossberg 2004). Aerial insectivores, however, show tremendous diversity in life history and ecology, so one might hypothesize that declines in this guild, which is defined by the insects they consume, are more likely connected to broad-scale changes in insect populations or phenology. In Britain, for example, long-term declines in macromoths (Conrad et al. 2006) and in native butterflies during the periods 1970 to 1982 and 1988 to 1991 (Thomas et al. 2004) have been attributed to changes in agricultural practices and proposed as reasons for declines in populations of aerial insectivores (Benton et al. 2002, Evans et al. 2007). Such multitrophic effects would be indicative of more fundamental ecosystem changes, thus making the issue especially important.

We first ask whether aerial insectivore populations across North America show more acute declines than other species and then examine whether those population trends vary geographically and through time. We further evaluate possible correlative factors that may suggest underlying causes of the observed declines. For data, we use the North
American Breeding Bird Survey (BBS) trend estimates from four decades (1966 to 2006) (Sauer et al. 2007) for southern Canada and the lower 48 United States. The BBS data set is based on surveys that are repeated each year during the breeding season along more than 4000 randomly distributed roadside routes, using a standardized protocol (Robbins et al. 1989, Sauer et al. 2003). Biases in the BBS database include roadside sampling and observer variability (Sauer et al. 1996, Link and Sauer 1998, Keller and Scallan 1999), but the standard protocol, the long time series, and the massive scale of the initiative nevertheless make it possible to study long-term population trends for most terrestrial bird species that breed in southern Canada and the continental U.S (Dunn 2001, Murphy 2003, Sauer et al. 2003, Lawler and O'Conner 2004).

\section{METHODS}

\section{Breeding Bird Survey data set}

We used population trend data for Canada and the United States for the period 1966 to 2006 obtained from the Breeding Bird Survey (BBS) website (Sauer et al. 2007). Population trends were expressed as percent change per year and were estimated using the route-regression method, whereby regional BBS trends are estimated as a weighted average of trends on individual routes (Sauer et al. 1994). We used U.S. states and Canadian provinces as our geographic units (jurisdictions). We did not use data from Alaska and Yukon because useful BBS data from these northern regions were of relatively recent origin and did not correspond with the time-frames of interest. Nor did we include species whose primary breeding range is south of the United States, and hence not well represented by BBS. We also excluded all trend estimates for any jurisdiction based on fewer than 15 routes, in accordance with BBS practice. We excluded Black Swift Cypseloides niger because it was represented in too few (3) jurisdictions. Species that have been taxonomically separated since the BBS began were treated as single species (Pacific Slope and Cordilleran Flycatchers were "Western" Flycatcher, and Willow and Alder Flycatchers were "Traill's" Flycatcher). Scientific names of the 31 aerial insectivore species used in the analyses are given in Table 1. Our main data set contained 5305 records (trend by species and jurisdiction) from 58 
Table 1. Foraging strategy and migration distance assignments for aerial insectivores used in the analyses.

\begin{tabular}{|c|c|c|c|}
\hline Common name & Scientific name & Migration distance & Foraging strategy \\
\hline Common Nighthawk & Chordeiles minor & Long-distance & Hawker \\
\hline Common Poorwill & Phalaenoptilus nuttallii, & Short-distance & Sallier \\
\hline Chuck-will's-widow & Caprimulgus carolinensis & Short-distance & Sallier \\
\hline Whip-poor-will & Caprimulgus vociferus & Short-distance & Sallier \\
\hline Chimney Swift & Chaetura pelagica & Long-distance & Hawker \\
\hline Vaux's Swift & Chaetura vauxi & Short-distance & Hawker \\
\hline White-throated Swift & Aeronautes saxatalis & Short-distance & Hawker \\
\hline Olive-sided Flycatcher & Contopus cooperi & Long-distance & Sallier \\
\hline Western Wood-Pewee & Contopus sordidulus & Long-distance & Sallier \\
\hline Eastern Wood-Pewee & Contopus virens & Long-distance & Sallier \\
\hline Yellow-bellied Flycatcher & Empidonax flaviventris & Short-distance & Sallier \\
\hline Acadian Flycatcher & Empidonax virescens & Long-distance & Sallier \\
\hline Willow/Alder Flycatcher & Empidonax traillii/alnorum & Long-distance & Sallier \\
\hline Least Flycatcher & Empidonax minimus & Short-distance & Sallier \\
\hline Hammond's Flycatcher & Empidonax hammondii & Short-distance & Sallier \\
\hline Gray Flycatcher & Empidonax wrightii & Short-distance & Sallier \\
\hline Dusky Flycatcher & Empidonax oberholseri & Short-distance & Sallier \\
\hline Pacific Slope/Cordilleran Flycatcher & Empidonax difficilis/ occidentalis) & Short-distance & Sallier \\
\hline Eastern Phoebe & Sayornis phoebe & Short-distance & Sallier \\
\hline Say's Phoebe & Sayornis saya & Short-distance & Sallier \\
\hline Great Crested Flycatcher & Myiarchus crinitus & Short-distance & Sallier \\
\hline Western Kingbird & Tyrannus verticalis & Short-distance & Sallier \\
\hline Eastern Kingbird & Tyrannus tyrannus & Long-distance & Sallier \\
\hline Scissor-tailed Flycatcher & Tyrannus forficatus & Short-distance & Sallier \\
\hline Purple Martin & Progne subis & Long-distance & Hawker \\
\hline Tree Swallow & Tachycineta bicolor & Short-distance & Hawker \\
\hline Violet-green Swallow & Tachycineta thalassina & Short-distance & Hawker \\
\hline Northern Rough-winged Swallow & Stelgidopteryx serripennis & Short-distance & Hawker \\
\hline Bank Swallow & Riparia riparia & Long-distance & Hawker \\
\hline Cliff Swallow & Petrochelidon pyrrhonota & Long-distance & Hawker \\
\hline Barn Swallow & Hirundo rustica & Long-distance & Hawker \\
\hline
\end{tabular}


jurisdictions (10 provinces, 48 states); $18 \%$ ( $n=$ $955)$ of the records were aerial insectivores and $82 \%$ $(n=4350)$ were other passerines.

\section{Modeling population trends}

To test whether observed declines in aerial insectivores were different from all other passerines (two assemblages) we calculated the number of species declining vs. not declining in each combination of jurisdiction and assemblage type. To minimize taxonomic effects, we elected to do the comparison using only passerine aerial insectivores (24 of 31 species in the main data set). We modeled the log-odds of the number of species declining (trend $<0$ ) versus the number not declining (trend $\geq 0$ ) in each jurisdiction as a function of latitude, longitude, and assemblage type. Latitude and longitude values for each jurisdiction were determined using midpoints approximated from Google Earth. Midpoints for Canadian provinces from Quebec westwards were shifted south to account for the southerly distribution in BBS routes in those jurisdictions.

\section{Modeling factors correlated with population trends}

We then further evaluated factors related to trends solely within the 31 species of aerial insectivores. We did this by considering trend as a binary variable (declining vs. not declining) and using logistic regression to assess whether the probability of a species declining was correlated with any of the following six variables: latitude, longitude, foraging strategy (de Graaf et al. 1985, Poole 2005), migration distance (Poole 2005), foraging height (Poole 2005), and nest height (Environment Canada 2009a). For foraging strategy (Table 1), the swallows, swifts, and Common Nighthawk (11 species) were designated as hawkers (foraging by constant flying), and the tyrant flycatchers and other nightjars (20 species) were designated as salliers (foraging by periodic forays from a perch). For migration distance (Table 1), 12 species whose main winter range is in South America were designated long-distance and the remaining 19 species as shortdistance. When ranges were given for foraging height and nest height, we calculated the mean. We used three foraging height categories $(<10 \mathrm{~m}=$ low, 10 to $50 \mathrm{~m}=$ medium, 75 to $2500 \mathrm{~m}=$ high) and three nest height categories $(0 \mathrm{~m}=$ ground, 1 to 6.75 $\mathrm{m}=$ low; 7 to $24 \mathrm{~m}=$ high). Because we had multiple observations of species within each jurisdiction, and multiple observations of jurisdictions for each species, we treated those variables as random effects in a mixed model.

We also analyzed the timing and extent of the decline in the northeastern part of the range, where the declines were most pronounced. We used annual indices computed using BBS data from two bird conservation regions in eastern Canada, i.e., the Boreal Hardwood Transition and the Atlantic Northern Forest (Environment Canada 2009b). For each species' time series, we fit a generalized additive model (Wood 2006) of the annual index vs. year, and used the fitted values from that model to determine the points of local maxima and minima (using the first derivative). We then calculated an annualized percent change (trend) in the index between each of those periods and examined plots of the annualized trends by year to assess the timing of declines in the northeast.

We visualized the continental pattern of decline for a subset of aerial insectivores (those predominantly found east of the $100^{\text {th }}$ meridian) to assess the overall distribution of declining vs. increasing trends across jurisdictions.

\section{Statistical analyses}

Statistical analyses were done in $R$, version 2.10 .0 (R Development Team 2010). Logistic models were fit using lmer (logit link and binomial errors) in Package 'Ime4' (Bates and Maechler 2010) to include random effects for species and jurisdictions and the gam function in Package 'mgcv' (Wood 2006). Models were fit using backward selection (testing fixed effects using a $z$ statistic, and comparing nested models using likelihood ratio tests) beginning with an initial model containing no interaction terms. Overall fit was assessed visually using residual plots and by inspection of parameter estimates (e.g., proper convergence, reasonable standard errors). Although there were large differences across species/jurisdictions in the quality of the trend estimates, assigning weights to these based on estimates of statistical significance was not straightforward and could have eliminated information. Instead, we assessed the effects of trend estimate quality on parameters by refitting the 
Table 2.Parameter estimates from a general linear model (logit link, binomial errors) assessing whether population declines in aerial insectivorous passerines ( 24 species) differed from other passerines (186 species). The model assessed the effect of latitude, longitude, and assemblage ('aerial insectivore' or 'other') on the odds of species declining (number of species with trend $<0$ vs. number of species with trend $\geq 0$ ) within each of 58 North American jurisdictions (states and provinces).

\begin{tabular}{lcccc}
\hline \hline Parameter & Estimate & SE & Z & $\mathrm{p}$ \\
\hline Assemblage & -0.661 & 0.697 & -0.95 & 0.342 \\
Latitude & -0.039 & 0.013 & -2.96 & 0.003 \\
Longitude & 0.020 & 0.005 & 4.27 & $<0.001$ \\
Assemblage $\times$ latitude & 0.047 & 0.014 & 3.30 & 0.001 \\
Assemblage $\times$ longitude & -0.014 & 0.005 & -2.68 & 0.007 \\
\hline
\end{tabular}

models using only data from 'significant' trends ( $p$ $<0.1)$. The signs of the parameters did not differ between the two sets of models; the magnitude of the estimates was, as expected, higher for all parameters in the restricted set.

\section{RESULTS}

\section{Are aerial insectivores declining more strongly than other passerines?}

We found a significant survey-wide interaction between assemblage type and both latitude and longitude on the odds of a species declining (Table 2). Aerial insectivores in the east and north of North America are disproportionately more likely to be declining (Table 2, Fig. 1, Fig. 2) than are other passerine species in these areas.

\section{Factors correlated with population declines}

The probability of decline for an aerial insectivore was significantly related to migration distance, latitude, and longitude (Table 3). Long-distance migrants (largely wintering in South America) were more likely to have declining populations than short-distance migrants. Furthermore, the estimated magnitudes of trends were greater for those species wintering in South America (median: $-1.1 \%$ per year) than in Central America ( $-0.25 \%$ per year). The probability of an aerial insectivore declining increased eastward as well as northward, which is consistent with the pattern that emerged when aerial insectivores were compared to other passerines (Fig. 2). There was no evidence that foraging strategy, foraging height, or nest height correlated with the pattern of decline.

\section{Timing of the population declines}

Plots of the pattern of change within the two eastern Canadian bird conservation regions show that after 1980 virtually all population trends are negative (Fig. 3). Prior to 1980, trends show varying patterns. A linear model of magnitude of trend vs. year of onset of trend confirms that trends are increasingly negative over time (glm with Gaussian errors, Ftest, $p<0.001)$ (Fig. 4).

\section{DISCUSSION}

Declines in aerial insectivore songbirds were first noted about two decades ago (Böhning-Gaese et al. 1993) and have continued to this day. Our analysis of North American Breeding Bird Survey trend estimates shows that passerines of the aerial insectivore guild incurred significantly stronger declines between 1966 and 2006 compared to other 
Fig. 1. The proportion of species declining in each jurisdiction (states and provinces), and locally weighted regression lines for aerial insectivorous passerines (circles and solid lines) and for all other passerines (squares and stippled lines) in the lower 48 United States and in southern Canada. Aerial insectivores in the east and north of North America are disporpotionately more likely to be declining than other passerine species in these areas.
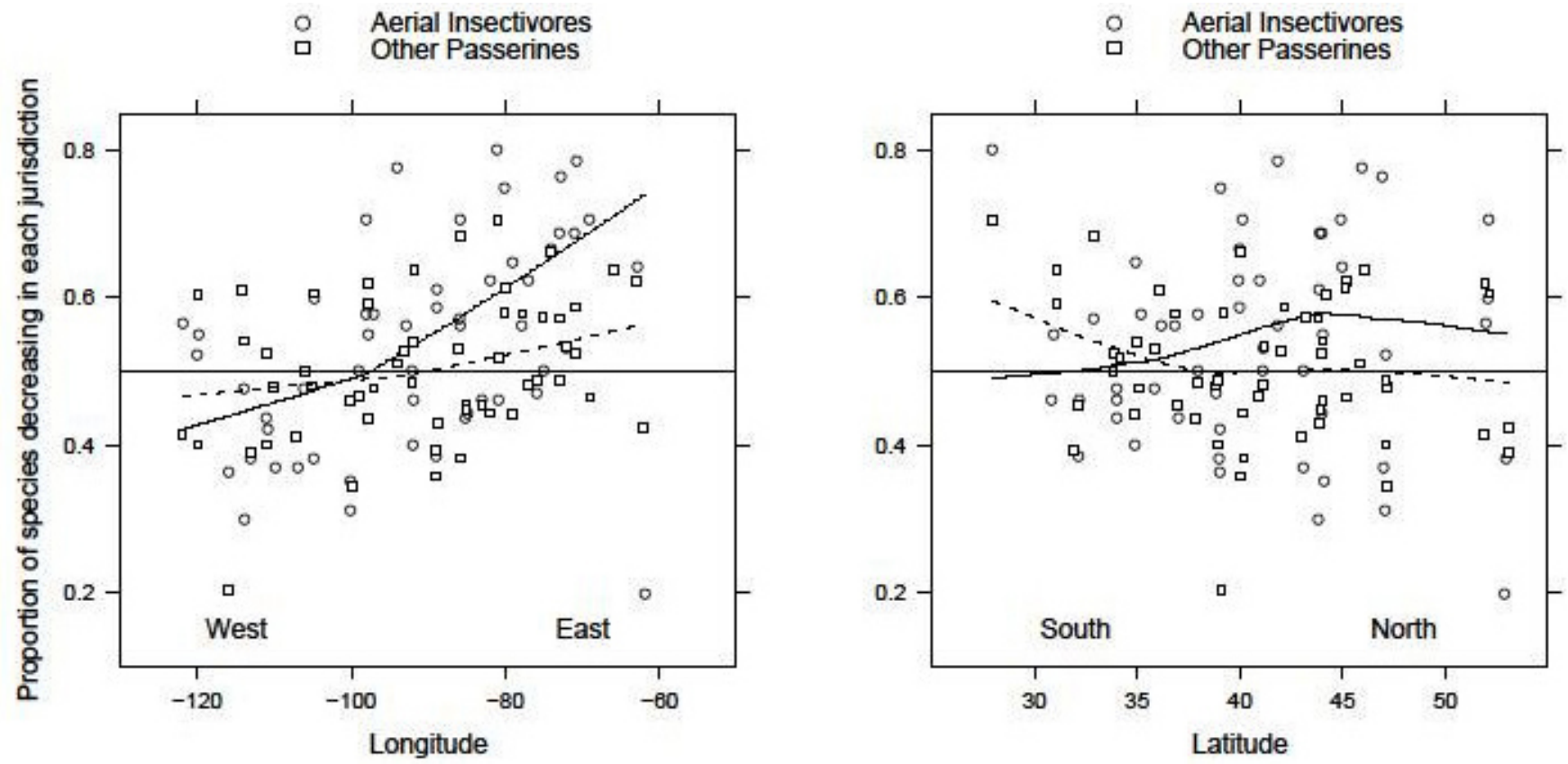

passerines. Furthermore, we show a striking geographical gradient in the population trends of aerial insectivores, with the probability of decline being the highest in northeastern North America. Declining trends predominate after 1980 and are most acute in species migrating to and from South America.

\section{Geographic gradients}

There is generally a greater degree of industrialization and human density as one moves northeastward in North America, making it possible that some correlate of the human footprint might explain the pattern observed. Yet aerial insectivore declines are greatest where industrialization and density again start to diminish, i.e., as one moves northward in Canada. The observed pattern is consistent with the footprint of long-range transport of atmospheric pollutants. Human activity in industrial north-central United States and southern Ontario produces atmospheric conditions that negatively affect acid-sensitive Precambrian landscapes in the north and east. The attendant effects on soils and water (Schindler et al. 2006) are correlated with declines in insect abundance and diversity (Graveland 1998). Given that the common attribute among the aerial insectivores is their dependency on insect prey, general declines in insect abundance could well negatively influence populations. One persistent effect of acid precipitation is the reduction of environmental calcium. An estimated 21 to $75 \%$ of eastern Canada is receiving acid deposition in excess of critical loads (Morrison 2005). As a result, calcium stores are declining (Watmough and Dillon 2003), which has a negative effect on aquatic food webs (Jeziorski et al. 2008).

Climate change can also generate geographic gradients of ecological response because of regional 
Fig. 2. Distribution maps for a selection of 15 species of aerial insectivores showing geographic patterns of population trends, according to the Breeding Bird Survey (1966 to 2006) (Sauer et al. 2007). Jurisdictions where a species was present on fewer than 15 routes were not plotted.

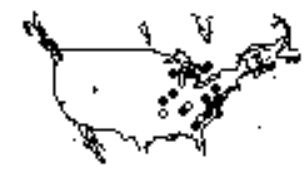

Whip-poor-will

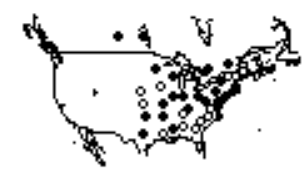

Great Crested Flycatcher

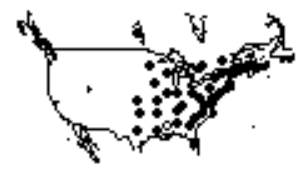

Eastern Wood-Pewee

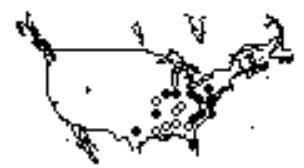

Acadian Flycatcher

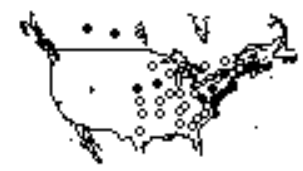

Eastern Phoebe

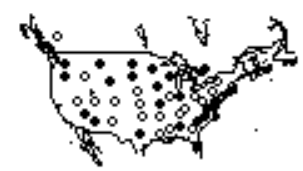

N. Rough-winged Swallow

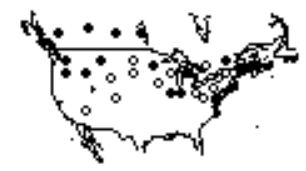

Willow/Alder Flycatcher

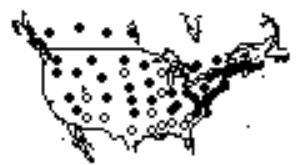

Barn Swallow

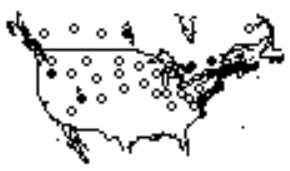

Tree Swallow

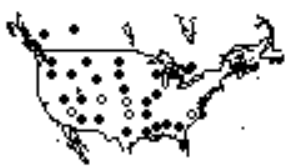

Common Nighthawk

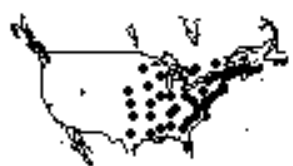

Chimney Swift

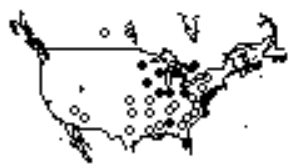

Purple Martin

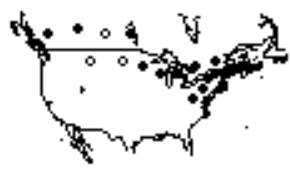

Least Flycatcher

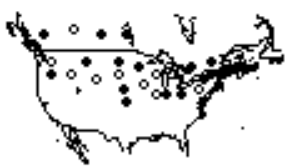

Bank Swallow

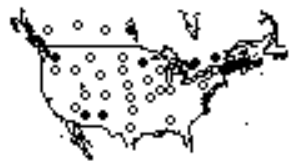

Cliff Swallow

o increase

- decrease differences in climate responses to atmospheric change. For example, decadal variation in the Pacific's El Niño Southern Oscillation (ENSO, a broad-scale climate cycle influenced by climate change) has been shown to be related to the fecundity of eastern North American insectivorous birds (Sillett et al. 2000) as well as their behavior on migration (Calvert et al. 2009). Similarly, variation in the North Atlantic Oscillation has been shown to be related to survivorship in male House Martins Delichon urbicum in southwestern Germany (Stokke et al.2005). Although broad-scale geographic changes in climate have the capacity to influence populations, whether they can account for the geographical gradients in aerial insectivore declines remains unknown.
Directional change in insect abundance and phenology generated by climate change (Aukema et al. 2008, Kozlov 2008) will not be uniform across latitude or longitude. Such changes have been shown to directly influence insect abundance (through broad-scale processes such as range shifts; e.g., butterflies (Parmesan 2006)) which in turn could produce the broad-scale geographic patterns of trends that we observe here. Indirectly, asynchrony in the timing of breeding compared to the availability of food for nestlings has been implicated in large ( $90 \%)$ population declines for at least one species, Pied Flycatcher Ficedula hypoleuca (Visser et al. 1998, Visser and Both 2005, Both et al. 2006). 
Fig. 3. Population trends in two eastern Canadian bird conservation regions: A) Boreal Hardwood Transition, and B) Atlantic Northern Forest. The red points are the Breeding Bird Survey annual abundance indices; the black line is the fitted value of a generalized additive model (see text). Arrows indicate a change in slope. All aerial insectivores in the two regions are shown. After 1980, virtually all population trends are declining.
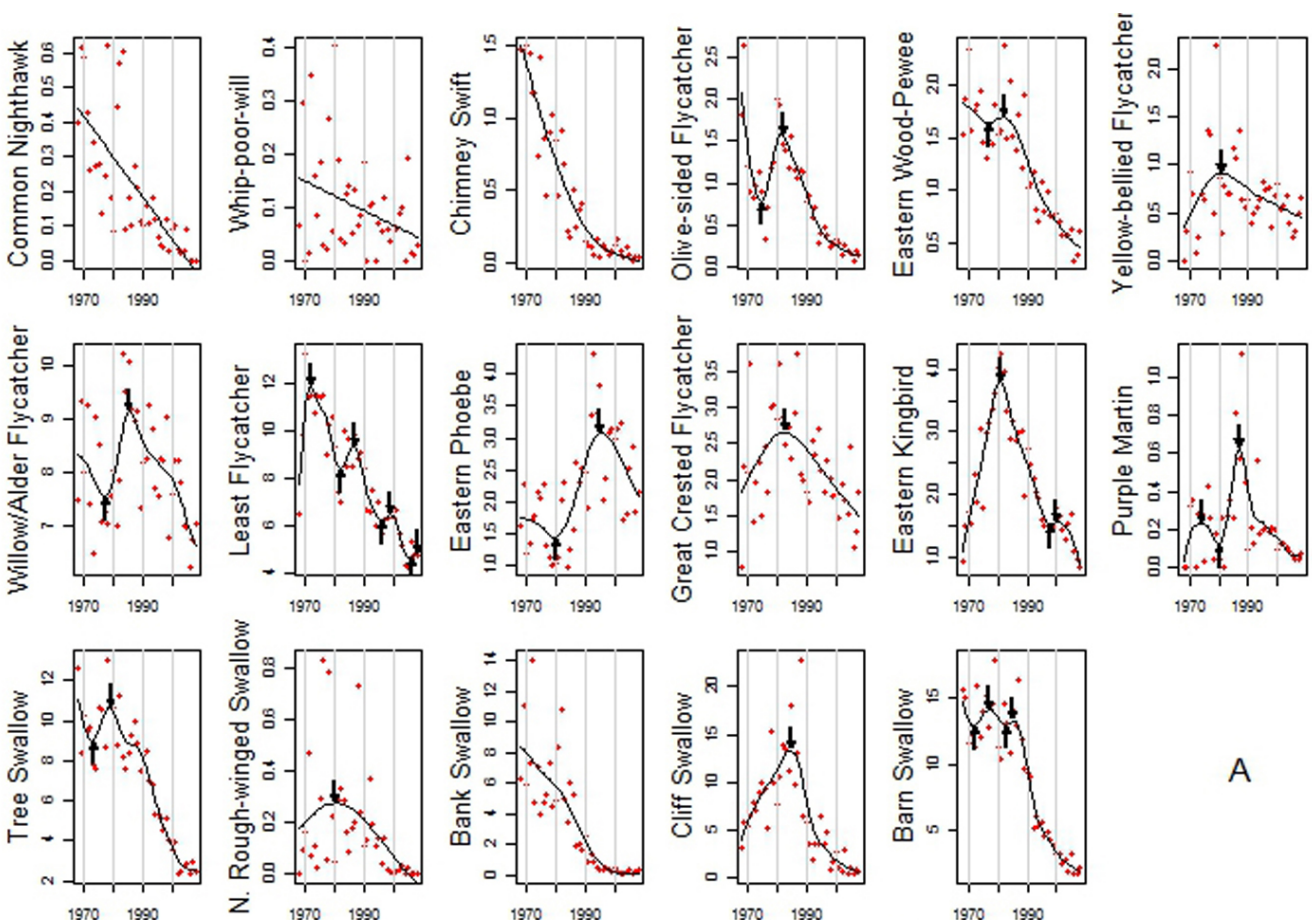

A
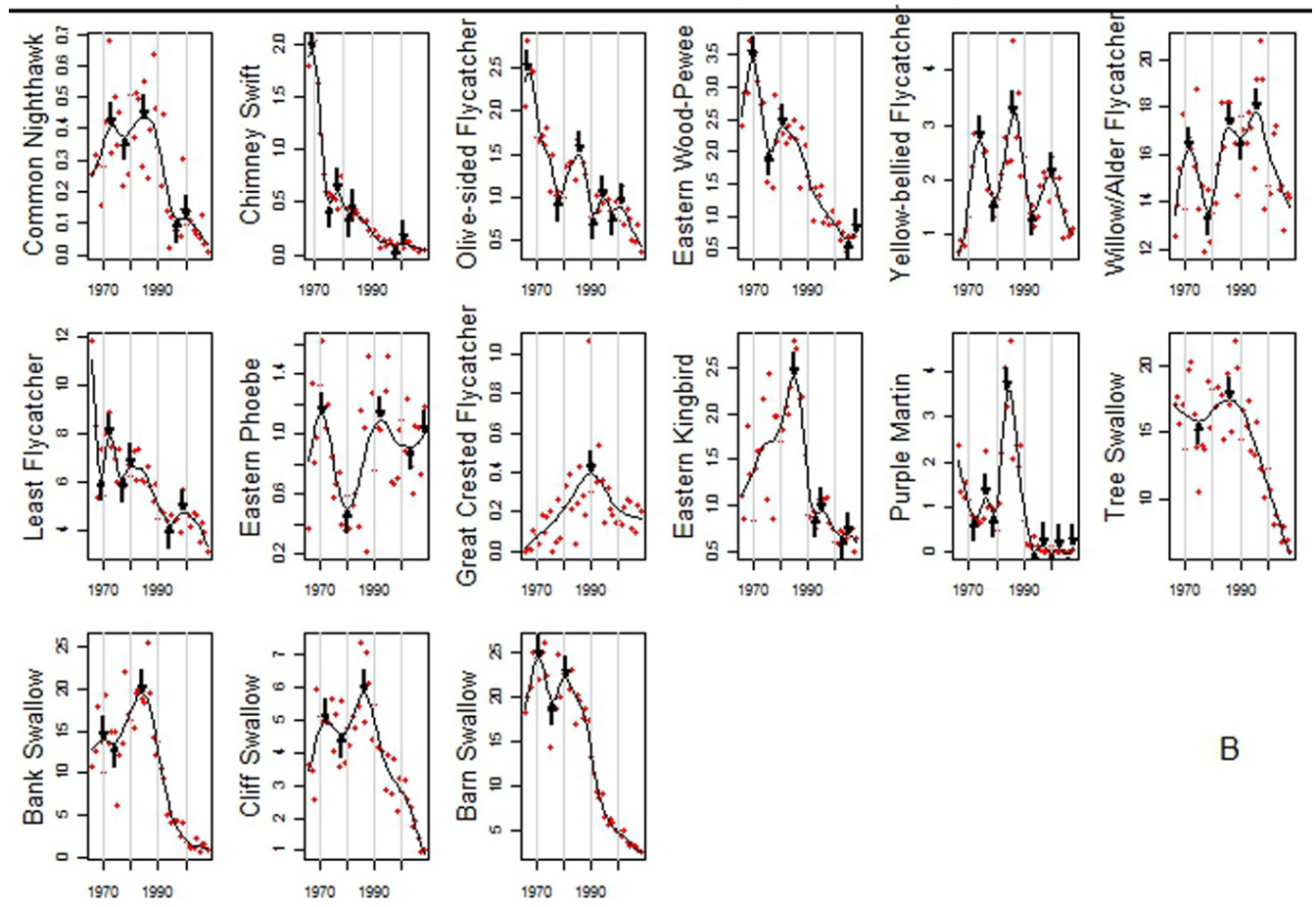
Table 3. Parameter estimates from a generalized linear mixed model (logit link, binomial errors) assessing the effects of latitude, longitude, and migration distance (reference category, long distance) on the binomial trend variable (decreasing vs. increasing/no trend).

\begin{tabular}{lcccccc}
\hline \hline Fixed effects & Estimate & SE & Z value & $\mathrm{P}$ & $\begin{array}{c}\text { Random } \\
\text { effects }\end{array}$ & Variance \\
\hline Latitude & 0.071 & 0.020 & 3.505 & $<0.001$ & $\begin{array}{c}\text { Jurisdiction } \\
\text { (58 groups })\end{array}$ & 0.170 \\
Longitude & -0.021 & 0.008 & -2.650 & 0.008 & $\begin{array}{c}\text { Species } \\
(31 \text { groups })\end{array}$ & 1.536 \\
Migration distance & -1.241 & 0.508 & -2.441 & 0.015 & & \\
\hline
\end{tabular}

Such changes are unlikely to be straightforward and linear because of cross-scale interactions and feedbacks in the systems. Even so, an examination of temporal trends in temperature and rainfall data across the continent may yield some insight. For example, one could erect plausible hypotheses regarding observed and expected changes in insect phenology with observed geographical gradients in temperature and rainfall, or more indirectly, with patterns of climatic indices. Care needs to be taken with this type of analysis as some ecological effects can manifest themselves with time lags, or through interactions with other effects, and direct causal relationship may not be present.

\section{Timing of the declines}

We are not aware of any sudden or unique largescale ecological changes that occurred in the 1980s that might correspond to the timing of the observed declines. However, there are well-documented regime shifts in ocean systems within the past few decades that are linked to broad-scale climatic indices such as ENSO and North Atlantic Oscillation (Blenckner and Hillebrand 2002). It is likely that comparable or related shifts may occur in terrestrial systems. It is also possible that ecological changes occurred earlier than the observed onset of the declines, but did not immediately manifest themselves at the population level. In bird populations, a floating population of non-breeding individuals will buffer losses in the breeding population until the floater population ceases to exist (Durell and Clarke 2004). Also, initial declines in common species are much less noticeable than later declines of species that are evidently in trouble (León-Cortéz et al. 1999).

\section{Migratory distance}

Passerine mortality is thought to be highest during migration (Sillett and Holmes 2002), a factor that might drive the observed correlation between migratory distance and decline, especially as environmental change can impoverish migration stopover habitat (Baker et al. 2004). Additionally or alternatively, stressors that are more acute in distant wintering areas, such as pesticide use, might play a role. Declines in insect abundance and diversity are certainly connected to pesticides (Goldstein et al. 1999), and organochlorine pesticides are still used in Central and South America, where almost all North American aerial insectivores overwinter. Pesticides can affect aerial insectivores directly by reducing their prey base, and indirectly through effects on reproduction (Colburn et al. 1993). We show that declines are more prevalent in long-distance migrants (e.g., those that winter in South America) than in shortdistant migrants (most of which winter in Central America). If pesticides are more heavily used in South America than in Central America (which seems unlikely), then the declines might be a direct effect of higher mortality of birds wintering in South 
Fig. 4. Patterns of change across all species of aerial insectivores by year. Prior to 1980, trends show varying patterns, but trends become increasingly negative over time. Circles show the annualized trend between change points (from Figure 3, including the beginning and ending of each time series) plotted by the initial year. The sizes of circles are proportional to the square root of the duration of the trend (so larger circles represent trends over longer time periods). The horizontal (trend $=0$ ) and vertical (year $=$ 1980) lines are provided for reference. Trends are only shown for periods exceeding 4 years.

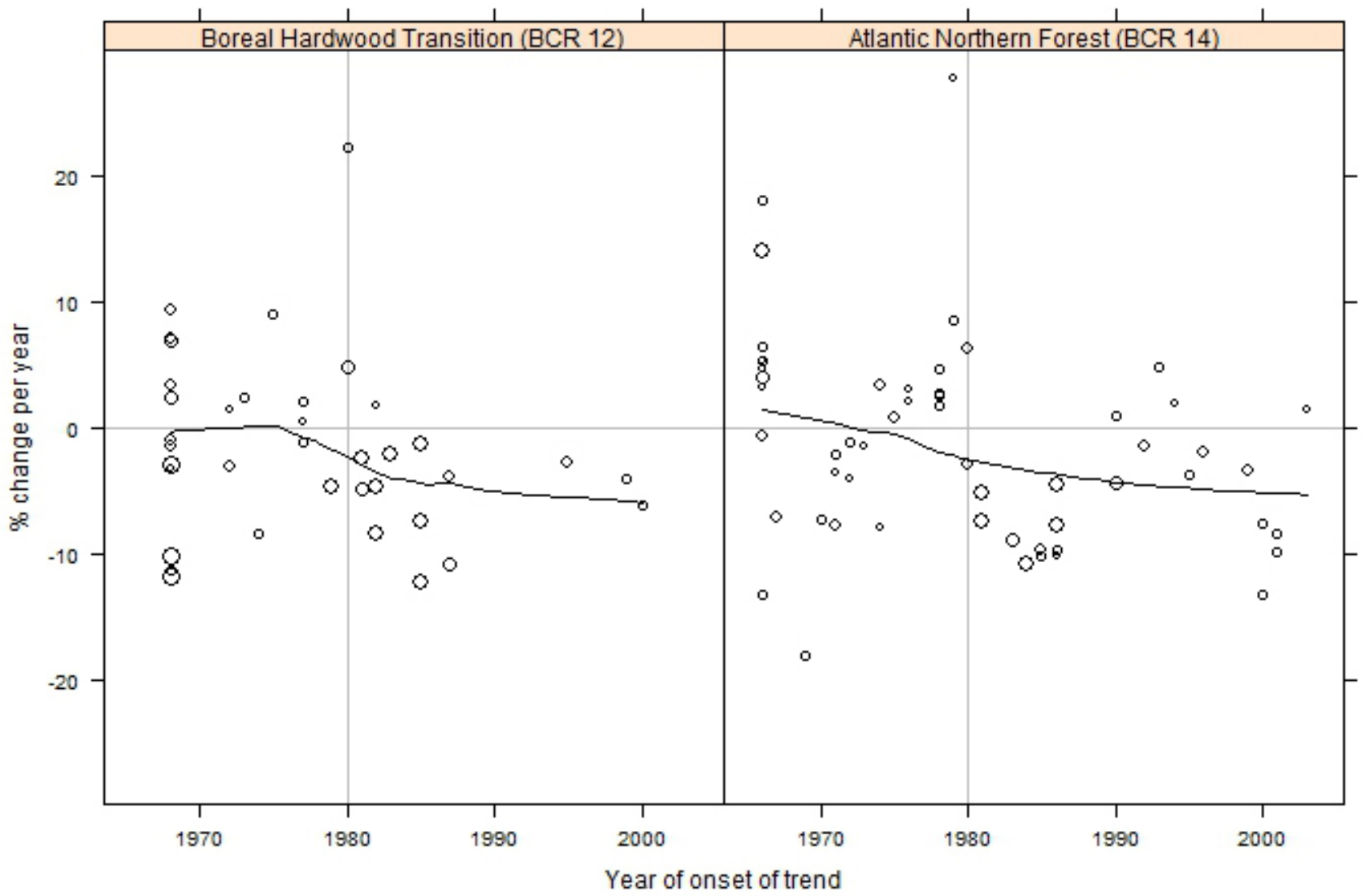

America. Alternatively, the difference might be caused by the increased energetic demands on longdistance migrants, for which the indirect effects of reduced habitat quality through any of a number of mechanisms comes at a greater cost. Previous studies have shown that neotropical migrant insectivores migrating north through the United States had significantly higher levels of organochlorine pesticides than non-insectivores (Klemens et al. 2000). Likewise, insectivorous birds breeding in areas of high agricultural and industrial activity in Texas accumulated environmental contaminants, including organochlorines (Mora et al. 2006). 
Responses to this article can be read online at:

http://www.ace-eco.org/vol5/iss2/artl/responses/

\section{Acknowledgments:}

We wish to acknowledge the efforts of thousands of Breeding Bird Survey (BBS) participants who contributed to the data base. We thank Brian Collins (Environment Canada) who calculated BBS trend estimates for us for two BBS regions in eastern Canada. All other trends we used were produced by personnel associated with the Patuxent Wildlife Research Centre and the United States Geological Survey. Chris Guglielmo (University of Western Ontario) is thanked for valuable input at the planning stage of the project. Mike Cadman (Environment Canada) provided useful references and insights. This project was funded through the University of Western Ontario, an NSERC Discovery Grant to Philip Taylor, and Bird Studies Canada. Thanks also to Beacon Environmental for a special financial contribution.

\section{LITERATURE CITED}

Andren, H. 1994. Effects of habitat fragmentation on birds and mammals in landscapes with different proportions of suitable habitat: a review. Oikos 71:355-366.

Aukema, B. H., A. L. Carroll, Y. Zheng, J. Zhu, K. F. Raffa, R. D. Moore, K. Stahl, and S. W. Taylor. 2008. Movements of outbreak populations of mountain pine beetle: influences of spatiotemporal patterns and climate. Ecography 31:348-358.

Baines, D. 2008. The direct and indirect effects of predation by Hen Harriers Circus cyaneus on trends in breeding birds on a Scottish grouse moor. Ibis 150:27-36.

Baker, A. J., P. M. González, T. Piersma, L. J. Niles, I. de Lima Serrano do Nascimento, P. W. Atkinson, N. A. Clark, C. D. T. Minton, M. K. Peck, and G.Aarts. 2004. Rapid population decline in red knots: fitness consequences of decreased refuelling rates and late arrival in Delaware Bay. Proceedings of the Royal Society of London Series B-Biological Sciences 271:875-882.
Bates, D., and M. Maechler. 2010. Linear and fixed effects models using S4 classes. Version 0.999375-34. R Foundation for Statistical Computing, Vienna, Austria. [online] URL: http://c ran.r-project.org/web/packages/lme4/lme4.pdf. [cited 2010 June]

Benton, T. G., D. M. Bryant, L. Cole, and H. Q. P. Crick. 2002. Linking agricultural practice to insect and bird populations: a historical study over three decades. Journal of Applied Ecology 39:673-687.

Bird Studies Canada. 1986. Maritimes breeding bird atlas. Sackville, New Brunswick, Canada. [online] URL: http://www.mba-aom.ca/english/index. html [cited 2010 April].

Blenckner, T., and H. Hillebrand. 2002. North Atlantic oscillation signatures in aquatic and terrestrial ecosystems - a meta-analysis. Global Change Biology 8:203-212.

Böhning-Gaese, K., M. L. Taper, and J. H. Brown. 1993. Are declines in North American insectivorous songbirds due to causes on the breeding range? Conservation Biology 7:76-86.

Both, C., S. Bouwhuis, C. M. Lessells, and M. E. Visser. 2006. Climate change and population declines in a long-distance migratory bird. Nature 44:81-83.

Cadman, M. D., D. A. Sutherland, G. G. Beck, D. Lepage, and A. R. Couturier. 2007. Atlas of the breeding birds of Ontario, 2001-2005. Bird Studies Canada, Environment Canada, Ontario Field Ornithologists, Ontario Ministry of Natural Resources, and Ontario Nature, Toronto, Ontario, Canaca.

Calvert, A. M., P. D. Taylor, and S. Walde. 2009. Cross-scale environmental influences on migratory stop-over behaviour. Global Change Biology 15:744-759.

Colburn, T., F.S. Vom Saal, and A. M. Soto. 1993. Developmental effects of endocrine-disrupting chemicals in wildlife and humans. Environmental Health Perspectives 101:378-384.

Conrad, K. F., M. S. Warren, R. Fox, M. S. Parsons, and I. P. Woiwod. 2006. Rapid declines of common, widespread British moths provide 
evidence of an insect biodiversity crisis. Biological Conservation 132:279-291.

COSEWIC. 2009. Canadian wildlife species at risk. Committee on the Status of Endangered Wildlife in Canada, Canadian Wildlife Service, Environment Canada, Ottawa, Ontario, Canada. [online] URL: http://www.cosewic.gc.ca/eng/sct5/i ndex e.cfm.

de Graaf, R. M., N. G. Tilghman, and S. H. Anderson. 1985. Foraging guilds of North American birds. Environmental Management 9:493-536. [cited 2009 October]

Dionne, M., C. Maurice, J. Gauthier, and F. Shaffer. 2008. Impact of Hurricane Wilma on migrating birds: the case of the Chimney Swift. Wilson Journal of Ornithology 120:784-792.

Dunn, E. H. 2001. Using decline in bird populations to identify needs for conservation action. Conservation Biology 16:1632-1637.

Durell, S. E. A. L. V. d., and R. T. Clarke. 2004. The buffer effect of non-breeding birds and the timing of farmland bird declines. Biological Conservation 120:375-382.

Environment Canada. 2009a. Wildspace. Ottawa, Ontario, Canada. [online] URL: http://wildspace.ec. gc.ca/intro-e.html. [cited 2008 April 5]

Environment Canada. 2009b. Migratory birds conservation, monitoring and reporting, bird conservation regions (BCRs). Canadian Wildlife Service, Ottawa, Ontario, Canada. [online] URL: http://www.cws-scf.ec.gc.ca/mgbc/trends/index.cfm?

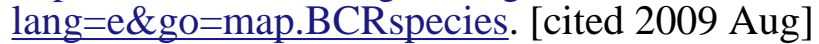

Evans, K. L., J. D. Wilson, and R. B. Bradbury. 2007. Effects of crop type and aerial invertebrate abundance on foraging barn swallows Hirundo rustica. Agriculture Ecosystems \& Environment 122:267-273.

Goldstein, M. I., T. E. J. Lacher, B. Woodbridge, M. J. Bechard, S. B. Canavelli, M. E. Saccagnini, G. P. Cobb, E. J. Scollon, R. Tribolet, and M. J. Hooper. 1999. Monocrotophos-induced mass mortality of Swainson's Hawks in Argentina, 199596. Ecotoxicology 8:201-214.

Graveland, J. 1998. Effects of acid rain on bird populations. Environmental Review 6:41-54.
Jeziorski, A., N. D. Yan, A. M. Paterson, A. M. DeSellas, M. A. Turnter, D. S. Jeffries, B. Keller, R. C. Weeber, D. K. McNicol, M. E. Palmer, K. McIver, K.Arseneau, B. K. Ginn, B. F. Cumming, and J. P. Smol. 2008. The widespread threat of calcium decline in fresh waters. Science 322:1374-1377.

Keller, C. M., and J. T. Scallan. 1999. Potential roadside biases due to habitat changes along Breeding Bird Survey routes. Condor 101:50-57.

Klemens, J. A., R. G. Harper, J. A. Frick, A. P. Capparella, H. B. Richardson, and M. J. Coffey. 2000. Patterns of organochlorine pesticide contamination in neotropical migrant passerines in relation to diet and winter habitat. Chemosphere 41:1107-1113.

Kozlov, M. V. 2008. Losses of birch foliage due to insect herbivory along geographical gradients in Europe: a climate-driven pattern. Climate Change 87:107-117.

Lawler, J. J., and R. J. O' Conner. 2004. How well do consistently monitored breeding bird survey routes represent the environments of the conterminous United States? Condor 106:801-814.

León-Cortéz, J. L., M. J. R. Cowley, and C. D. Thomas. 1999. Detecting decline in a formerly widespread species: how common is the common blue butterfly Polyommatus icarus? Ecography 22:643-650.

Link, W. A., and J. R. Sauer. 1998. Estimating population change from count data: application to the North American Breeding Bird Survey. Ecological Applications 8:258-268.

MacHunter, J., W. Wright, R. Loyn, and P. Rayment. 2006. Bird declines over 22 years in forest remnants in southeastern Australia: evidence of faunal relaxation? Canadian Journal of Forest Research 36:2756-2768.

McGowan, K. J., and K. Corwin. 2008. The second atlas of breeding birds in New York State. Cornell University Press, Ithaca, NY.

Mora, M. A., D. Musquiz, J. W. Bickham, D. S. Mackenzie, M. J. Hooper, J. K. Szabo, and C. W. Matson. 2006. Biomarkers of exposure and effects of environmental contaminants on swallows nesting 
along the Rio Grande, Texas, USA. Environmental Toxicology and Chemistry 25:1574-1584.

Morrison, H.A., editor. 2005. 2004 Canadian acid deposition science assessment-summary of key results. Environment Canada, Ottawa, Ontario, Canada.

Murphy, M. T. 2003. Avian population trends within the evolving agricultural landscape of eastern and central United States. Auk 120:20-34.

Parmesan, C. 2006. Ecological and evolutionary responses to recent climate change. Annual Review of Ecology, Evolution, and Systematics 37:637-69.

Poole, A. 2005- . The birds of North America online. Cornell Laboratory of Ornithology, Ithaca, New York, USA. [online] URL: http://bna.birds.co rnell.edu/BNA/species. [cited 2009 October]

R Development Team. 2010. R: A language and environment for statistical computing. Version 2.10.10. R Foundation for Statistical Computing, Vienna, Austria. [online] URL: http://www.r-project. org/. [cited 2010 May]

Robbins, C. S., J. R. Sauer, R. S. Greenberg, and S. Droege. 1989. Population declines in North American birds that migrate to the neotropics. Proceedings of the National Academy of Sciences of the United States of America 86:7658-7662.

Robinson, S. K., F. R. Thompson III, T. M. Donovan, D. R. Whitehead, and J. Faaborg. 1995. Regional forest fragmentation and the nesting success of migratory birds. Science 267:1987-1990.

Sauer, J. R., J. E. Fallon, and R. Johnson. 2003. Use of North American Breeding Bird Survey data to estimate population change for bird conservation regions. Journal of Wildlife Management 67:372-389.

Sauer, J. R., J. E. Hines, and J. Fallon. 2007. The North American Breeding Bird Survey, results and analysis 1966-2006. Version 10.13.2007. USGS Patuxent Wildlife Research Center, Laurel, Maryland, USA. [online] URL: http://www.mbr-pw rc.usgs.gov/bbs/bbs2006.html. [cited 2009 Oct]

Sauer, J. R., G. W. Pendleton, and B. G. Peterjohn. 1996. Evaluating causes of population change in North American insectivorous songbirds. Conservation Biology 10:465-478.

Sauer, J. R., B. G. Peterjohn, and W. A. Link. 1994. Observer differences in the North American Breeding Bird Survey. Auk 111:50-62.

Schindler, D. W., P. J. Dillon, and H. Schreier. 2006. A review of anthropogenic sources of nitrogen and their effects on Canadian aquatic ecosystems. Biogeochemistry 79:25-44.

Sillett, T. S., and R. T. Holmes. 2002. Variation in survivorship of a migratory songbird throughout its annual cycle. Journal of Animal Ecology 71:296-308.

Sillett, T.S., R. T. Holmes, and T. W.Sherry. 2000. Impacts of a global climate cycle on population dynamics of a migratory songbird. Science 288:2040-2042.

Stokke, A. G., A. P. Møller, B.-E. Sæther, G. Rheinwald, and H. Gutscher. 2005. Weather in the breeding area and during migration affects the demography of a small long-distance passerine migrant. Auk 122:637-647.

Thomas, J. A., M. G. Telfer, D. B. Roy, C. D. Preston, J. J. D. Greenwood, J. Asher, R. Fox, R. T. Clarke, and J. H. Lawton. 2004. Comparative losses of British butterflies, birds, and plants and the global extinction crisis. Science 303:1879-1881.

Visser, M. E., and C. Both. 2005. Shifts in phenology due to global climate change: the need for a yardstick. Proceedings of the Royal Society of London Series B-Biological Sciences 272:2561-2569.

Visser, M. E., A. J. van Noordwijk, J. M. Tinbergen, and C. M. Lessells. 1998. Warmer springs lead to mistimed reproduction in great tits (Parus major). Proceedings of the Royal Society of London Series B-Biological Sciences 265:1867-1970.

Ward, M. P., and S. Schlossberg. 2004. Conspecific attraction and the conservation of territorial songbirds. Conservation Biology 18:519-526.

Watmough, S. A., and P. J. Dillon. 2003. Base cation and nitrogen budgets for seven forested catchments in central Ontario 1983-1999. Forest Ecology Management 177:155-177. 
Wood, S. N. 2006. Generalized additive models: an introduction with $R$. Chapman \& Hall, Boca Raton, Florida, USA.

Ydenberg, R. C., R. W. Butler, D. B. Lank, B. D. Smith, and J. Ireland. 2004. Western sandpipers have altered migration tactics as peregrine populations have recovered. Proceedings of the Royal Society of London Series B-Biological Sciences 271:1263-1269. 